\title{
₹USGS
}

science for a changing world

Prepared for the National Aeronautics and Space Administration

\section{Geologic Map of the Athabasca Valles Region, Mars}

By Laszlo P. Keszthelyi, Alexandra E. Huff, and Windy L. Jaeger

Pamphlet to accompany

Scientific Investigations Map 3477

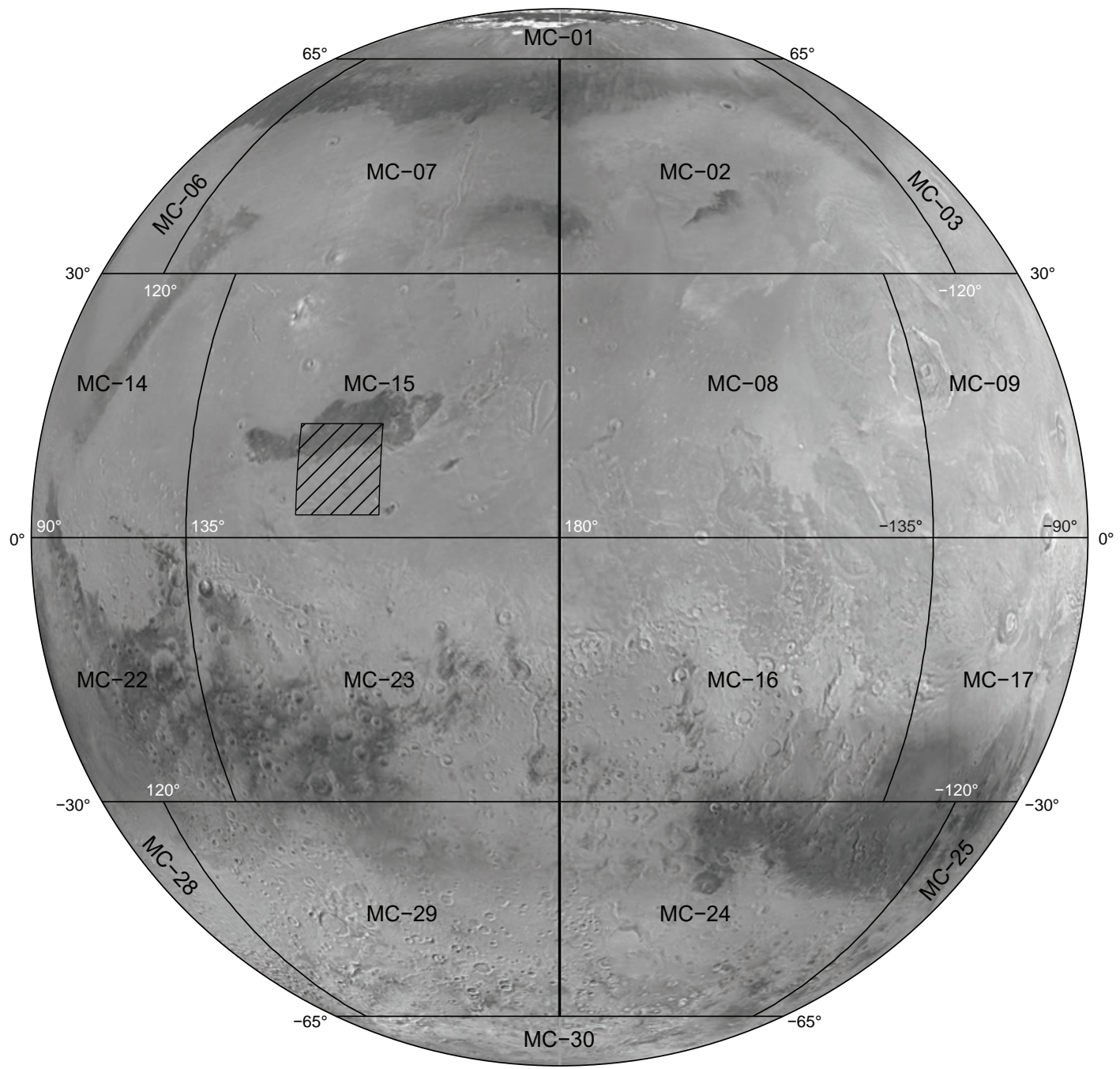

2021

U.S. Department of the Interior

U.S. Geological Survey 


\section{U.S. Geological Survey, Reston, Virginia: 2021}

For more information on the USGS - the Federal source for science about the Earth, its natural and living resources, natural hazards, and the environment-visit https://www.usgs.gov or call 1-888-ASK-USGS.

For an overview of USGS information products, including maps, imagery, and publications, visit https://store.usgs.gov.

Any use of trade, firm, or product names is for descriptive purposes only and does not imply endorsement by the U.S. Government.

Although this information product, for the most part, is in the public domain, it also may contain copyrighted materials as noted in the text. Permission to reproduce copyrighted items must be secured from the copyright owner.

Suggested citation:

Keszthelyi, L.P., Huff, A.E., and Jaeger, W.L., 2021, Geologic map of the Athabasca Valles region, Mars: U.S. Geological Survey Scientific Investigations Map 3477, pamphlet 11 p., 1 sheet, scale 1,000,000, https://doi.org/10.3133/sim3477.

ISSN 2329-1311 (print)

ISSN 2329-132X (online)

Cover. Photomosaic showing location of map area (hachured rectangle). An outline of 1:5,000,000scale Mars Chart quandrangles is provided for reference. 


\section{Contents}

Introduction

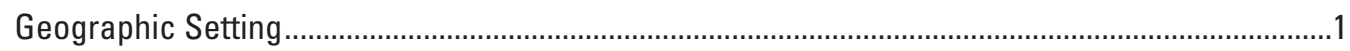

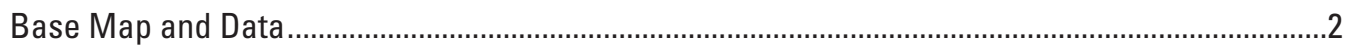

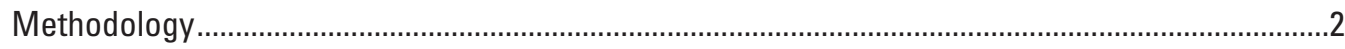

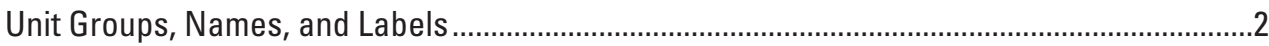

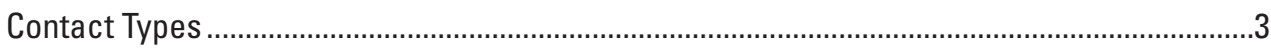

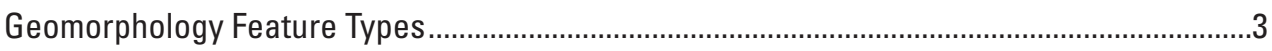

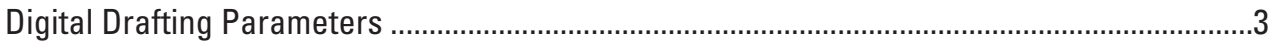

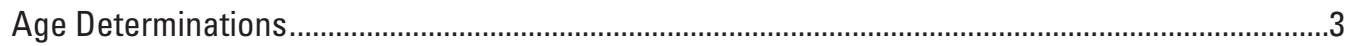

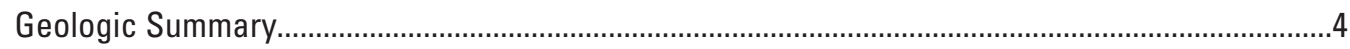

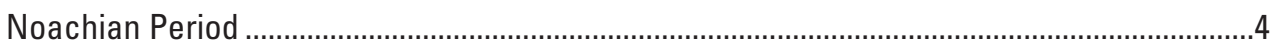

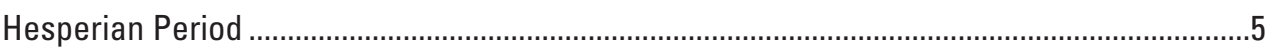

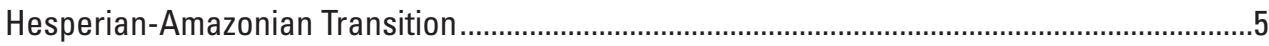

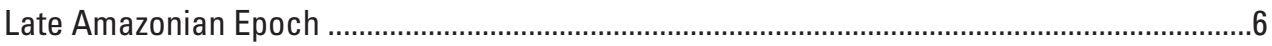

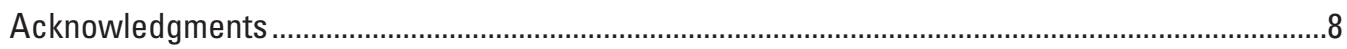

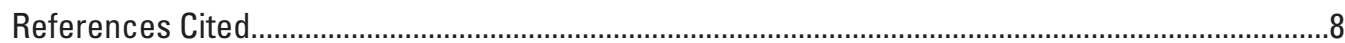

\section{Figures}

1. Topographic map showing the map area, the surrounding region, and the geographic feature names approved by the International Astronomical Union (IAU)............map sheet

2. Images showing how prominent features in the 100 meter per pixel (m/pixel) Thermal Emission Imaging System Infrared (THEMIS IR) basemap are misleading when mapping the very young lavas in our map area........................................map sheet

3. Image showing geographic features in units eNtm and Hnup ........................map sheet

4. Image showing the typical surface of unit eAer ...............................................map sheet

5. Images showing superposition relations between the Medusae Fossae Formation (AHmf) and Athabasca Valles Basalt (IAav) .......................................................map sheet

\section{Table}

1. Characteristics of geologic units in the Athabasca Valles region, Mars. 


\title{
Geologic Map of the Athabasca Valles Region, Mars
}

\author{
By Laszlo P. Keszthelyi, Alexandra E. Huff, and Windy L. Jaeger
}

\section{Introduction}

The youngest major channel system on Mars (Tanaka and Scott, 1986) is the focus of this 1:1,000,000-scale geologic map of central Elysium Planitia. The system starts at the Cerberus Fossae fissures, extends 300 kilometers $(\mathrm{km})$ through the network of channels known as Athabasca Valles, and then extends for more than another $1,000 \mathrm{~km}$ via a series of linked shallow basins that include Cerberus Palus. The work was originally funded by the National Aeronautics and Space Administration (NASA) in 2005 to address a vigorous scientific debate on the nature of the flood that carved Athabasca Valles, but Jaeger and others $(2007,2010)$ largely accomplished the original aims of that study. Over the following decade, this map has been fundamentally reworked to provide the contextual framework for new high-resolution studies of the near-pristine geologic features in the region. Previous studies placed the young activity into the broader geologic history of Mars (for example, Tanaka and others, 2005, 2014). The complex spatial and stratigraphic relations within these young terrains, however, have not been systematically documented. This geologic map addresses this need, laying the foundation for more detailed analyses in the future. We provide a brief synopsis of the decades of previous work in the area before discussing our map.

Athabasca Valles were first recognized in Viking Orbiter images that barely resolved the feature and were interpreted as the youngest outflow channel system on Mars formed by catastrophic aqueous floods (Tanaka and Scott, 1986). Subsequent Mars Global Surveyor, Mars Odyssey, and Mars Express data were not fully consistent with the valley system having been formed purely by erosional aqueous flood processes, leading to a lively - but inconclusive - debate between many competing hypotheses that called upon a variety of aqueous, marine, glacial, periglacial, mudflow, and volcanic processes (for example, Plescia, 1990, 2003; Tanaka and others, 1992, 2005; Mouginis-Mark, 1993; Edgett and Rice, 1995; Keszthelyi and others, 2000, 2004, 2007; Berman and Hartmann, 2002; Burr and others, 2002, 2004, 2005; Hoffman and Tanaka, 2002; Rice and others, 2002; Burr, 2003, 2005; Gaidos and Marion, 2003; Head and others, 2003; Werner and others, 2003; Manga, 2004; Hanna and Phillips, 2005; Murray and others, 2005; Page and Murray, 2006; Page, 2007).

When the Mars Reconnaissance Orbiter (MRO) arrived at Mars in 2006, the 25-30 centimeters per pixel (cm/pixel) High Resolution Imaging Science Experiment (HiRISE)
(McEwen and others, 2007) images showed that the floor of Athabasca Valles contained the remarkably pristine frozen remains of a fluid that had passed through the channels with abundant kinematic indicators showing flow along the local thalweg (Jaeger and others, 2007). Key features of the frozen flow include a fissure vent, rafted plates, polygonally fractured inter-plate texture, compressional ridges where plates collide, cratered cones, large-scale fill-and-spill mode of movement between topographic basins, raised plateaus with lava-rise textures, and distal margins transitioning from simple sheets to meter-scale lobes. These features are all common on mafic lava flows across the solar system (for example, Keszthelyi and others, 2006; Jaeger and others, 2007, 2010; Hamilton and others, 2015). Based on a detailed kinematic analysis, Jaeger and others (2007) concluded that the cratered cones within Athabasca Valles are phreatovolcanic features that formed during the latter part of the emplacement of a large lava flow, leading them to reject the non-lava hypotheses. After a few questions (Page, 2007, 2010) were addressed (Jaeger and others, 2008,2010 ), peer-reviewed publications generally agree that the flow in Athabasca Valles is mafic lava (Boisson and others, 2009; Keszthelyi and others, 2010; Harmon and others, 2012; Ryan and Christensen, 2012; Cataldo and others, 2015; Noguchi and Kurita, 2015; Cassanelli and Head, 2018; Golder and others, 2020), though mudflows are still considered for some similar flows outside our map area (for example, Wilson and Mouginis-Mark, 2014).

\section{Geographic Setting}

Our map area is defined as Mars Transverse Mercator (MTM) quadrangles 05202, 05207, 10202, 10207 (fig. 1). These quadrangles are located in equatorial lowlands of central Elysium Planitia, spanning $10^{\circ}$ of longitude and latitude (lat $150^{\circ}$ to $160^{\circ} \mathrm{E}$. and long $2.5^{\circ}$ to $12.5^{\circ} \mathrm{N}$.). The map area is centered on Athabasca Valles, which start at the Cerberus Fossae and debouch into Cerberus Palus. Lethe Vallis is the eastern exit from this basin, pointing toward the low rises of the Cerberus Tholi. The southern boundary of the map area clips the northern edge of Zephyria Planum, and the northern boundary includes the southernmost extent of the broad high centered on Elysium Mons, Albor Tholus, and Hecates Tholus (herein referred to as the Elysium rise). The southwestern-most part of the Tartarus Montes is located in the northeast corner of the map. 


\section{Base Map and Data}

When this map was originally proposed in 2005, the plan was to use a controlled mosaic of Viking Orbiter images (Kirk and others, 2000) as the basemap and to create four sheets at 1:500,000 scale to capture hectometer-scale features. However, in updating the purpose of this map, we revised this approach to a single sheet at 1:1,000,000 with the new 100 meter per pixel (m/pixel) controlled Mars Odyssey Thermal Emission Imaging System (THEMIS) (Christensen and others, 2004) daytime infrared mosaic as the basemap (Fergason and Weller, 2019). However, we could not resolve many of the key features on our basemap (fig. 2). Instead, we determined that $25-30 \mathrm{~cm} /$ pixel HiRISE images (McEwen and others, 2007) were essential for identifying contacts and $6 \mathrm{~m} /$ pixel MRO Context Camera (CTX) images (Malin and others, 2007) were the most useful for following them across the map area. We downloaded over 300 CTX images from the NASA Planetary Data System, processed them using the U.S. Geological Survey (USGS) Integrated Software for Imagers and Spectrometers Version 3 (ISIS3), and added them to our geographic information system (GIS) project. We did not formally quantify the spatial uncertainty in the CTX images, but we noted that misalignment with the controlled THEMIS basemap was commonly on the order of hundreds of meters. Future geologic mapping would benefit from a controlled CTX image mosaic. We did not import HiRISE images directly into our GIS project. Instead, we examined them with a variety of visualization tools to understand the nature of contacts and features visible in the CTX data. The geologic insights we gained from examining the HiRISE data guided the mapping on the CTX data. We also used topography from the Mars Global Surveyor (MGS) Mars Orbital Laser Altimeter (MOLA) (Zuber and others, 1992), both as individual shot points and interpolated (gridded) maps, to assist our mapping in GIS.

We found many other datasets indirectly useful in our mapping. These included a host of Mars orbiting spectrometers and orbital and Earth-based radar observations. We used published results from the Shallow Radar (SHARAD) instrument (Seu and others, 2004) in our interpretation of the shallow subsurface geology, but the data were not directly used in our mapping. Infrared spectral data can be very useful in many areas of Mars but were confounded by the ubiquitous dust mantle in this region (Ruff and Christensen, 2002; Jaeger and others, 2010). Even tonal variations in the visible images are strongly correlated with small-scale surface roughness as opposed to the petrology of the rocks under the dust (fig. 2). The MGS Gamma Ray Spectrometer (GRS) (Boynton and others, 2004) is the only instrument that has the potential to provide geochemical data from beneath a thin surficial cover. However, our examination of the published GRS maps found that the effective spatial resolution was too low to provide useful information at the scale of our mapping.

\section{Methodology}

We constructed the geologic map of the Athabasca Valles area using methods that blend best practices for traditional planetary geologic mapping (for example, Tanaka and others, 2005) with classic terrestrial field geology (for example, Compton, 1985). As such, we strove to map lithochronostratigraphic units rather than surfaces with consistent morphologic characteristics. More specifically, we first mapped the margins of discrete deposits formed within specific time intervals (in other words, defined allostratigraphic units). Next, we inferred lithology from geomorphology and geologic context. Then, relative stratigraphic position was determined from superposition and crosscutting relations. Finally, we estimated absolute age/chronology from crater counts. For the best-preserved Late Amazonian units, this process was straightforward and similar to mapping volcanic terrains on Earth. However, for older units, we often could not delineate the products of individual geologic events and we reverted to practices more typical in planetary geologic mapping. For example, we combined the products of multiple similar events into a single map unit. Similarly, we were not able to make confident determinations of the lithology and stratigraphy of the older (Noachian-Hesperian) units. We discuss the variations in uncertainties in our summary of the geologic history of the region. In the rest of this section, we describe the methods used to ascribe (1) unit groups, names, and symbols, (2) types of geologic contacts, and (3) types of feature symbols. The section ends with details of the digital drafting parameters used to compile information.

\section{Unit Groups, Names, and Labels}

We named the geologic units that occur within the Athabasca Valles area by balancing the need to be informative while avoiding potentially erroneous genetic connotations and preserving objectivity (Salvador, 1994; Hansen, 2000; Tanaka and others, 2005). Part of this philosophy includes avoiding exaggerating uncertainty. Therefore, where there was unusually strong evidence for a specific lithology (not just mineralogy or geochemistry) associated with a formation (for example, Keszthelyi and others, 2006; Jaeger and others, 2007, 2010; Hamilton and others, 2015), we followed terrestrial convention and included the lithology in the formal unit name (for example, Athabasca Valles Basalt). Following usage in field mapping on Earth, the term "basalt" in this context allows compositions ranging from basaltic-andesites to picrites (for example, the Grande Ronde Basalt of the Columbia River Basalt Group are mostly basaltic andesites). We were able to follow this convention for the best-preserved young units with observations made in sub-meter HiRISE images. For even slightly older and more eroded units, we reverted to the convention used in most planetary geologic mapping and do not specify a lithology. Where possible, we used existing unit names at the formation level from earlier regional and global maps (for example, Medusae Fossae Formation). When the unit did not have an obvious previous name, we used a nearby prominent geographic feature for the unit name (for example, Athabasca Valles Basalt).

We subdivided the Cerberus Tholi Basalt into distinct subunits (in other words, members of the formation). We did not name these members individually but designated relative age relations between them using the "older/younger" $(\mathrm{O} / \mathrm{Y})$ 
symbols along internal contacts on the map (see Explanation of Map Symbols). A similar subdivision of older units was found to be impractical. For example, we found compelling evidence for discrete deposits formed at distinct times within the Medusae Fossae Formation but were unable to find reliable criteria with which to locate the contacts between these member-level units. Within this map area, we did not find it necessary or helpful to link multiple formations into stratigraphic units at a higher (group) level.

We followed the method used by Tanaka and others (2014) to label units. The capitalized letter indicates the period of the unit (A for Amazonian, $\mathrm{H}$ for Hesperian, $\mathrm{N}$ for Noachian). Where the age is known to the epoch level, this is indicated with a lowercase letter in front of the period. The age is followed by lowercase letters from the formation name. Thus, the Late Amazonian Cerberus Tholi Basalt is labeled IAct. We selected unit colors from the USGS print color chart for terrestrial geologic maps, attempting to follow the general convention of brown/ purple for the oldest units, green/blue for intermediate age units, and reddish hues for younger units. This conveniently matched another convention where volcanic units are generally given red hues with brighter tones for younger units.

\section{Contact Types}

We delineated geologic units within the map area using contacts that are attributed with their interpreted level of certainty. A geologic contact designated "certain" denotes the most precise contact between well-characterized geologic units with clear local superposition relations visible in available orbital images. In many instances, these relations are only clear at the CTX or HiRISE scale and not in the THEMIS infrared (IR) basemap (fig. 2). A geologic contact designated "approximate" is regarded as less precise in its spatial placement owing to data quality, subtlety of contact, or partial obscuration by surficial deposits.

\section{Geomorphology Feature Types}

We identified four types of positive-relief landforms, three types of negative-relief landforms, two types of orientation features, and two types of crater features within our map area. The symbology we used follows precedents established in previous terrestrial and planetary geologic maps (for example, Federal Geographic Data Committee, 2006; Tanaka and others, 2011) and are defined in the Explanation of Map Symbols (map sheet). Topographic features were mapped as follows: ridge crests along the center of the feature (type 1 and type 2); flow fronts and terrace scarps along the upper topographic margin of those features; scarp bases along the lower topographic inflection point; and narrow fissures, lineaments, and a channel (volcanic) along the center of the feature. Orientation features were used to graphically represent local to regional trends rather than every individual feature. Crater features were mapped along the bounding topographic crest of circular to semicircular, bowl-shaped to flat-floored depressions; both sharp and degraded or buried rims were mapped for craters larger than $5 \mathrm{~km}$ in diameter.

\section{Digital Drafting Parameters}

The map was compiled using GIS software. In addition to the THEMIS IR basemap, CTX and MOLA data were included as layers in the working GIS project. We analyzed HiRISE data outside of GIS using a variety of image visualization tools. We digitized points, lines, and polygons using the digital streaming capability in GIS. Contacts and other features were often examined in CTX images at a scale of 1:25,000 to 1:50,000. We digitized vector linework at a scale of about 1:250,000 (400 percent of the publication map scale), which allowed for substantially detailed lines for use in a hardcopy map publication, as well as a digital product, while remaining true to the publication map scale of $1: 1,000,000$. Vertex spacing was set to place points within linework at $250 \mathrm{~m}$ (1 vertex per 1 millimeter at 1:250,000 digitizing map scale).

Linework was streamed using digital mapping tablets into a GIS digital geodatabase in Transverse Mercator projection (center longitude of $155^{\circ} \mathrm{E}$.). The geodatabase housed the attribute information for each digitized feature, which was assigned iteratively using attribute domain settings stored within the geodatabase. We used geologic map symbols that are derived from the Federal Geographic Data Committee Digital Cartographic Standards for Geologic Map Symbolization (Federal Geographic Data Committee, 2006) and adapted these where necessary to convey the geologic information unique to this area. Iterations of the digitized linework allowed for refinement of contact placement and unit descriptions based on cross comparison between the map base and supplemental datasets. We cleaned the contact linework to remove dangles and used these lines to build unit polygons. To balance the resolution of the base map and promote a clear, consistent cartographic representation, all unit outcrops are $>5$ square kilometers $\left(\mathrm{km}^{2}\right)$ and line features are $>2 \mathrm{~km}$ long. Absolute positioning on the surface of Mars is, on average, more accurate than $\pm 100 \mathrm{~m}$, based on the quality of the control of the THEMIS data to the MOLA-based control network (Fergason and Weller, 2018).

\section{Age Determinations}

The ages of planetary surface units are typically estimated from the cumulative densities of impact craters. The NoachianHesperian boundary is estimated to be between 3.74 and 3.56 billion years ago $(\mathrm{Ga})$ and the Hesperian-Amazonian boundary sometime between 3.46 and 3.01 Ga (Werner and Tanaka, 2011; Michael, 2013). Detailed analyses of impact-crater statistics often use cumulative size distribution plots, but we followed a simpler approach that is commonly used in planetary geologic mapping. This method relies on the number of craters greater than 1,5 , and $16 \mathrm{~km}$ in diameter per million $\mathrm{km}^{2}$, denoted as $\mathrm{N}(1), \mathrm{N}(5)$, and $\mathrm{N}(16)$. We followed the recommendations of Werner and Tanaka (2011) who defined the Early Noachian to Middle Noachian boundary at $\mathrm{N}(16)=200$, the Middle Noachian to Late Noachian at $\mathrm{N}(16)=100$, the Late Noachian to Early Hesperian at $\mathrm{N}(5)=200$, the Early Hesperian to Late Hesperian at N(5)=100, the Late Hesperian to Early Amazonian at $\mathrm{N}(1)=2,100$, the Early Amazonian to Middle Amazonian at $\mathrm{N}(1)=600$, and the Middle Amazonian to Late Amazonian at $\mathrm{N}(1)=160$. 
We used an existing database of impact craters (Robbins and Hynek, 2012) to calculate the density of impact craters for each of our units. We first determined the unit within which the center of each crater fell. Then, we examined each of the 334 craters individually in THEMIS and (or) CTX images to determine if the unit designation was correct. When the crater was embayed, it was often incorrectly assigned to a younger unit. When the crater was only partially embayed, identifying the unit that was impacted was straightforward. However, many of the smaller craters were surrounded, and sometimes overtopped, by later units. In these ambiguous cases, the craters were assigned to the undifferentiated plains unit (Hnup) unless evidence was compelling to do otherwise. One crater in the database was the drained lava pond at the summit of one of the Cerberus Tholi and was deleted from the crater statistics.

Uncertainties in the crater statistics were calculated assuming a square root of $\mathrm{N}$ relation for the number of craters. The uncertainty in the area is small for units high in the stratigraphy but increases with age because units are buried or removed by erosion. We did not have a precise way to estimate the resulting uncertainties but chose values of 5 percent for the youngest lavas, because they are generally not eroded or covered, and 10 percent for the Elysium rise Formation that is only covered at its distal end. A value of 25 percent was chosen for the Medusae Fossae Formation and Nepenthes undifferentiated plains because their original extent can only be inferred because of erosion and burial. The uncertainty in the area of the Tartarus Montes Formation was estimated at 50 percent because remnant craters could be discerned despite extensive erosion and burial, making it especially difficult to estimate the area where ancient craters can be reliably counted.

The results of our crater statistics are presented in table 1. The epoch assignment was unambiguous for four of our units (the Athabasca Valles, Cerberus Tholi, Elysium rise, and Tartarus Montes Formations). The N(1) value for the Medusae Fossae Formation is consistent with an Amazonian age, whereas the large uncertainty in the N(5) value allows a Hesperian age. Combined with the complex superposition relations discussed later, we conclude that the Medusae Fossae Formation in our map area includes areas of both Amazonian and Hesperian ages. The age of the Nepenthes undifferentiated plains is the most difficult to determine. Our best estimate that includes embayed and buried craters indicates an Early Amazonian age. However, this must be an underestimate because some buried craters can no longer be discerned, especially under thicker parts of the Cerberus Tholi Basalt. When we only consider the parts of the Nepenthes undifferentiated plains that are not buried, N(1) indicates a Late Hesperian age whereas N(5) indicates an Early Hesperian age. Given these constraints, and the mapping of similar units to the west of our map (Tanaka and others, 2005, 2014; Skinner and Tanaka, 2018), we place this unit in the Hesperian but do not assign an epoch.

Other studies in and around our map area have used smaller craters to derive age estimates for the Athabasca Valles Basalt of 5 to $2 \mathrm{Ma}$ (Berman and Hartmann, 2002; Burr and others, 2002; Murray and others, 2005; Vaucher and others, 2009). However, the effect of secondary craters from the nearby young Zunil crater on these age estimates is difficult to assess (for example, McEwen and others, 2005; Werner and others, 2009). Though geologically significant, we do not show the rays of Zunil secondary craters on our map because they have already been mapped in detail by Preblich and others (2007).

\section{Geologic Summary}

In this section, we summarize the geologic history of the Athabasca Valles area of Mars on the basis of the geologic unit and landform mapping and stratigraphic determinations presented herein. Some of the units we mapped, especially units eNtm, Hnup, AHmf, and eHer, are better exposed in other parts of Mars. Therefore, our understanding of these units relies extensively on previous studies from locations beyond our map boundaries. Though we focused on the aspects of the region's geologic history that are known with some certainty, we also briefly discuss more speculative ideas that highlight potential areas for future research.

\section{Noachian Period}

Mars experienced intense impact cratering during the Noachian Period, which pervasively disrupted the surface to the point that it was marked by overlapping craters and crater ejecta. These surfaces dominate the southern highlands of Mars but are largely absent in the northern lowlands, presumably because of burial by Hesperian and later deposits (for example, Tanaka and others, 2014). One prominent exception is the Tartarus Montes, which extend into the northeast corner of this map. Similar outcrops are found throughout the map area in exposures ranging from 100-km-scale patches of rugged cratered terrain to isolated massifs and knobs. We mapped all these outcrops as the Tartarus Montes Formation (unit eNtm). Although the exposures of unit eNtm in this map area are too sparse and isolated to draw detailed geologic inferences, studies of other parts of Mars indicate that the highlands are likely to consist of a wide variety of lithologies including impact breccia and melt, volcanic rocks, and clastic sedimentary rocks of aeolian, fluvial, lacustrine, and mass-wasting origins (for example, Irwin and others, 2013; Tanaka and others, 2014). We infer a similar origin and character for unit eNtm.

The volcanoes of the Elysium rise (Elysium Mons, Hecates Tholus, and Albor Tholus) are located $>1,000 \mathrm{~km}$ northwest of the map area and were largely constructed in the Noachian (for example, Werner, 2009; Platz and Michael, 2011). However, as discussed later, the current surface in our map area is Early Amazonian. As with the similar but much larger Tharsis rise, the volcanic edifices were surrounded by an extensive apron of lava flows. On the north side of the Elysium rise, there is evidence of complex interactions between the flows and a thick ice-rich mantling deposit such that the origin of the flow (mud versus lava) is not always clear (for example, Mouginis-Mark, 1985; Pederson, 2013; Hamilton and others, 2018). However, this mantling deposit is largely absent on the southern part of the Elysium rise, which includes our map area, and the flows have been consistently interpreted as lava (for example, Tanaka and others, 1992, 2005, 2014). 
Table 1. Characteristics of geologic units in the Athabasca Valles region, Mars.

[Crater statistics for unit Hnup were examined in two ways: (1) looking only at surface exposures; (2) considering areas where craters show through thin cover. Abbreviations: A, Amazonian; e, Early; H, Hesperian; km², square kilometers; 1, Late; m, Middle; N, Noachian; N(x), number of craters greater than x kilometers in diameter per million $\mathrm{km}^{2} ;<$, younger than adjacent units; >, older than adjacent units]

\begin{tabular}{|c|c|c|c|c|c|c|c|c|}
\hline $\begin{array}{l}\text { Unit } \\
\text { label }\end{array}$ & Unit name & $\begin{array}{c}\text { Unit } \\
\text { area } \\
\left(\mathrm{km}^{2}\right)\end{array}$ & $\begin{array}{l}\text { Crater count } \\
\text { area }\left(\mathrm{km}^{2}\right)\end{array}$ & $N(1)$ & $N(5)$ & $N(16)$ & $\begin{array}{c}\text { Crater- } \\
\text { density } \\
\text { age }^{1}\end{array}$ & Superposition relations \\
\hline $\mathrm{AHmf}$ & Medusae Fossae Formation & 17,800 & $19,800 \pm 4,900$ & $910 \pm 286$ & $101 \pm 95.3$ & 0 & eA-eH & $<$ eNtm, Hnup, IAav; >IAct, IAav \\
\hline IAav & Athabasca Valles Basalt & 115,000 & $115,000 \pm 5,000$ & $8.71 \pm 9.17$ & 0 & 0 & lA & $<\mathrm{eNtm}$, Hnup, eAer, IAct, AHmf; >AHmf \\
\hline IAct & Cerberus Tholi Basalt & 59,100 & $59,100 \pm 2,900$ & $16.9 \pm 17.8$ & 0 & 0 & lA & <eNtm, Hnup, eAer, AHmf; >IAav \\
\hline eAer & Elysium rise Formation & 97,600 & $97,600 \pm 9,800$ & $1,900 \pm 155$ & $61.5 \pm 27.9$ & 0 & eA & $<$ eNtm, Hnup; >IAct, IAav \\
\hline \multirow[t]{2}{*}{ Hnup } & \multirow{2}{*}{$\begin{array}{l}\text { Nepenthes undifferentiated } \\
\text { plains }\end{array}$} & \multirow[t]{2}{*}{29,900} & $29,600 \pm 1,500$ & $2,530 \pm 292$ & $135 \pm 75.4$ & $33.7 \pm 33.7$ & $\mathrm{lH}-\mathrm{eH}$ & \multirow[t]{2}{*}{$<$ eNtm; >eAer, IAct, IAav, AHmf } \\
\hline & & & $202,000 \pm 50,000$ & $1,080 \pm 431$ & $54.6 \pm 22.9$ & $4.96 \pm 6.61$ & $\mathrm{eA}$ & \\
\hline eNtm & Tartarus Montes Formation & 9,930 & $12,100 \pm 6,100$ & $4,460 \pm 1,210$ & $1,160 \pm 793$ & $744 \pm 496$ & $\mathrm{eN}$ & >Hnup, eAer, IAct, IAav, AHmf \\
\hline
\end{tabular}

${ }^{1}$ Based on crater-density boundaries as determined by Werner and Tanaka (2011) and updated by Michael (2013).

\section{Hesperian Period}

The rugged topography of the heavily cratered Early Noachian highlands terrain was degraded and modified across the later Noachian and through the Hesperian, producing a broad plain that we map as the Nepenthes undifferentiated plains (Hnup). These plains are generally featureless even at HiRISE resolution (other than sufficient impact craters to indicate a Hesperian age) with a few lobate flow margins that are distinct enough to be shown on our map (fig. 3). The contact between unit Hnup and unit eNtm is ambiguous and commonly obscured by recent talus shed off the topographically higher (but stratigraphically lower) unit eNtm (fig. 3). The transition from ancient highlands to Hesperian plains is well expressed $>1,000$ $\mathrm{km}$ west of the map area in southern Utopia Planitia, where Terra Cimmeria transitions to Nepenthes Mensae and Nepenthes Planum (for example, Skinner and Tanaka, 2018). By including Nepenthes in the name of this plains unit, we intended to call attention to the similarity to the plains in this region. When compared to the units in the geologic map of the Nepenthes Planum region (Skinner and Tanaka, 2018), our unit Hnup exhibits characteristics most like their Hesperian Nepenthes Flow (Htnf) and Hesperian-Noachian Cimmeria 3 (HNhc3) units. We do not attempt to differentiate the units within the plains, hence the "undifferentiated" designation for unit Hnup.

Interpretation of the formation of unit Hnup was uncertain given the isolated outcrops in our map area. Therefore, we relied heavily on published studies of the westward extension of these materials along the highlands-lowlands transition in southern Utopia Planitia, especially Skinner and Tanaka (2018). Their plains units in the Nepenthes Mensae and Nepenthes Planum are interpreted as "intact and degraded sedimentary plains emplaced by fluvial, colluvial, and (or) lacustrine processes" and "lava and (or) sedimentary flows... [with] ...variable rugged to smooth textures from different eruptive styles and (or) erosional modification." Our observations were concordant with these interpretations. However, in our map area, some of the flows plausibly include lavas from the Elysium rise that are isolated from, and older than, those we mapped as unit eAer.

\section{Hesperian-Amazonian Transition}

The deposition of the Medusae Fossae Formation (AHmf) in the map area may have started in the Late Hesperian and continued through the Amazonian. This unit has been extensively studied in the past (for example, Scott and Tanaka, 1982; Greeley and Guest, 1987; Bradley and others, 2002; Irwin and others, 2004; Mandt and others, 2008; Carter and others, 2009; Harrison and others, 2010; Kerber and Head, 2010, 2012; Zimbelman and Griffin, 2010; Zimbelman and Scheidt, 2012; Morgan and others, 2015). In particular, Kerber and Head (2010) and Morgan and others (2015) published detailed examinations of the northern part of Zephyria Planum, which is the main exposure of unit AHmf in our map area. This unit forms rounded mounds and mesas $100 \mathrm{~km}$ in length and tens of kilometers wide. The surfaces of these mounds are ubiquitously eroded into yardangs (wind-carved ridges) that are typically many kilometers long, $>100 \mathrm{~m}$ high, and 1-5 km wide (Mandt and others, 2008). Their near-vertical sides show that the material is cohesive, even though it is easily abraded by windblown particles.

We found that the yardang orientations are generally consistent within a mound but vary greatly from mound to mound. This variety of yardang orientations has been noted across the Medusae Fossae Formation in previous publications (for example, Bradley and others, 2002; Kerber and Head, 2010; Zimbelman and Griffin, 2010). This indicates that unit AHmf is the product of multiple depositional and erosional events (for example, Mandt and others, 2009; Kerber and Head, 2012). An individual set of yardangs formed after a deposit of unit AHmf was emplaced and then eroded within a period when the wind regime was consistent enough to form yardangs. A different yardang set formed later as a new deposit was eroded in a different wind regime. However, to preserve the first set of yardangs, the first set must have become resistant to further wind erosion before the winds changed. This interpretation of multiple distinct deposits within unit AHmf is consistent with the interpretation of the MRO SHARAD data (Morgan and others, 2015). In principle, we should have divided unit AHmf into members that each formed at significantly different times. 
However, in practice, we were unable to identify criteria to reliably delineate such members. This may be possible with future higher-resolution investigations.

Interpretation of the Medusae Fossae Formation is strongly constrained by its exceptional radar properties that are discussed in previous studies. Earth-based and Mars-orbiting radar observations find that these materials absorb energy at 3.5 and $12.6 \mathrm{~cm}$ wavelengths while being unusually transparent at $>10$ m wavelengths (Muhleman and others, 1991; Harmon and others, 1999, 2012; Alberti and others, 2012). This requires that the surface have electrical properties very similar to the atmosphere and that these properties only change gradually over the upper tens of centimeters depth. This indicates that at least the upper part of unit AHmf is composed of a material with very high porosity (greater than 50 percent), which is higher than the typical dust deposits on Mars (Muhleman and others, 1991). The inference that unit AHmf has high porosity is supported by the presence of pedestal craters, which indicate that the impact process makes the unit more resistant to erosion, possibly by local compaction and sintering (Barlow, 2006; Kerber and Head, 2012). Combined modeling of the radar sounding and gravity data result in a best-fit density for the Medusae Fossae Formation of $1,765 \pm 105$ kilograms per cubic meter with a depth-averaged porosity of 45 percent (Ohja and Lewis, 2018).

One of the few natural materials that has porosity $>50$ percent, is easily eroded, and has enough cohesion to maintain steep vertical slopes is reticulite (basaltic pumice) (Keszthelyi and others, 2000). This is a common product of basaltic lava fountains on Earth and is likely to have formed on Mars. Being composed of glass and having a high surface to volume ratio, reticulite would be expected to undergo rapid and extensive chemical alteration and cementation, especially if exposed to corrosive fluids associated with volcanic eruptions (Kerber and Head, 2012). The high halogen and hydrogen content of unit AHmf reported by the MGS GRS would be consistent with such alteration (Boynton and others, 2007). Although the evidence is not conclusive, we considered redeposited basaltic rocks and sediments as the most plausible lithology for unit AHmf. Most previous investigations have favored similar interpretations involving the aeolian deposition of basaltic materials but do not specifically suggest reticulite (for example, Scott and Tanaka, 1982; Edgett and others, 1997; Bradley and others, 2002; Hynek and others, 2003; Mandt and others, 2008; Kerber and Head, 2010; Kerber and others, 2013; Morgan and others, 2015). The primary alternative hypothesis that remains under consideration is that the Medusae Fossae Formation is largely composed of water ice (for example, Schultz and Lutz, 1988; Watters and others, 2007), but we found that this matches fewer of the observations we and others have made.

In the northern part of our map area, the lava apron on the Elysium rise continued to expand laterally during the Late Hesperian and Early Amazonian (Werner, 2009; Platz and Michael, 2011). However, the crater statistics show that the surface lavas are Early Amazonian, so we designate the Elysium Rise Formation as unit eAer. With only the distal ends of these flows extending into the map area, we do not have a complete story of how these lavas were emplaced. However, the lavas are generally observed to be simple flows that are $\sim 10 \mathrm{~km}$ wide and a few tens of meters thick, often with evidence of broad or anastomosing central channels. A few flat-topped ridges run down the length of the flows for tens of kilometers. The flow surfaces are also extensively muted at the meter scale with what appears to be aeolian infill but retain small craters effectively (fig. 4). These characteristics are commonly associated with aa flows rather than pahoehoe or platy-ridged lavas (for example, Keszthelyi and others, 2004). This suggests moderately high flow rates and (or) a relatively viscous rheology for these lavas (Peterson and Tilling, 1980; Rowland and Walker, 1990).

The mantled and complexly overlapping nature of these flows makes it impractical for us to separate the products of distinct eruptive episodes. The degree of cratering on the different flows shows no obvious spatial pattern, which indicates the age progression of unit eAer lavas is not readily discernible within the map area. Also, with little contact between unit eAer and unit Hnup, we are unable to confirm the relative age relations indicated from crater counts. The one contact in the northeast corner of the map has substantial aeolian cover but has isolated localities where unit eAer can be seen embaying unit Hnup.

During and after the emplacement of unit eAer, the region was subjected to northwest-southeast compression, resulting in a set of prominent wrinkle ridges that deform some lavas from unit eAer and deflect others. These ridges strike northeast and are 100-200 km long, 50 m high, and spaced roughly $100 \mathrm{~km}$ apart. The folding at the surface that is manifest as wrinkle ridges is driven by buried thrust faults (Suppe, 1983). The topographic profile of a wrinkle ridge can suggest the vergence on the fault, with the steeper side of the wrinkle ridge typically forming at the front of the thrust (Okubo and Schultz, 2003). The most prominent ridges in this area show a consistent pattern of the southeast side thrusting over the northwest footwall of the fault. Although mapping in this one region is insufficient to establish the source of the regional stress regime, it is consistent with response to loading of the lithosphere as the Elysium rise grew, rather than to outward sliding along the interface between the Noachian crust and the younger volcanic materials (Okubo and Schultz, 2003).

\section{Late Amazonian Epoch}

The placid pace of geologic activity typical of the Late Amazonian was frenetically upset in our map area with a host of volcanic eruptions (Vaucher and others, 2009). These started with the emplacement of a series of fissure-fed sheet flows and low shields of the Cerberus Tholi Basalt (unit IAct) and culminated with the massive flood of lavas of the Athabasca Valles Basalt (unit IAav).

The extremely pristine nature of the lava surfaces allowed us to map the deposits from a minimum of 13 separate eruptive episodes that we classified as members of the Cerberus Tholi Basalt. As noted earlier, some of these relations could only be properly interpreted by examining HiRISE images to discern meter-scale features. For the younger members, the flows were followed upslope to their vents. Three members of unit IAct were fed from drained lava ponds atop shallow shield volcanoes. The slopes of these shields are $\sim 0.1$ percent ( $1 \mathrm{~m}$ elevation change per kilometer), typical of plains volcanism (Greeley, 1982) but much less than classic shield volcanoes that have slopes of $\sim 10$ 
percent (100 meters per kilometer [m/km]). Still, because these low shields are 20-200 km in diameter, they each contain a few to a few hundreds of cubic kilometers $\left(\mathrm{km}^{3}\right)$ of lava (Vaucher and others, 2009). We also identified a series of small fissure vents for unit IAct lavas as far as $150 \mathrm{~km}$ south of the main Cerberus Fossae fissures. Our mapping is consistent with previous studies that show the Cerberus Fossae served as the primary source of the young lavas found across Elysium Planitia (Plescia, 2003).

We mapped a population of smaller wrinkle ridges (labeled "ridge crest, type 2" on the map sheet) that are predominantly oriented northwest-southeast on the Late Amazonian lava surfaces. These ridges are relatively subtle features that we are not able to reliably identify in older terrains. They are largely confined to a zone $300 \mathrm{~km}$ south of the main Cerberus Fossae fissures. These ridges are perpendicular to the predominant orientation of the earlier, larger wrinkle ridges in units Hnup and eAer, which suggests that the stress regime shifted sometime between the Hesperian and Late Amazonian. The observation that structural features parallel to the Cerberus Fossae switch from extensional to compressional between 150 and $300 \mathrm{~km}$ from the main fissures may provide constraints useful for future investigations of syn- and post-eruption ground deformation related to the Late Amazonian eruptions.

The morphology of unit IAct lavas is notably different where it was emplaced onto unit Hnup as compared to where it flowed onto other young lavas. Small, deeply incised channels are cut into unit Hnup. The size and morphology of these channels are consistent with small-scale fluvial erosion (Vaucher and others, 2009; Thomas, 2013). However, the surface is coated with lava. We considered two scenarios as plausible: (1) the ground was ice rich and the lava flows melted this ice and the channels formed by the flow of wet sediment out from under the lava or (2) the lava mechanically eroded the relatively unconsolidated colluvium to form these channels. We were not able to determine which hypothesis is more likely, and we consider it is possible that both processes worked in tandem.

The spatial distribution of the members within unit IAct shows a general trend for younger units to be closer to the main Cerberus Fossae fissures. This could be simply the result of shorter older flows being covered by subsequent longer flows. However, the presence of kipukas of unit eNtm and unit Hnup within unit IAct indicates that unit IAct is relatively thin. Nearby SHARAD profiles support the geomorphologic indications that unit IAct is generally no more than a few tens of meters thick (Morgan and others, 2017).

The eruptions that formed unit IAct were followed by the far more voluminous eruption of the Athabasca Valles Basalt (unit IAav). This eruption is detailed in Jaeger and others (2007, 2010 ) and only a brief summary is provided here. The lavas were erupted out of two distinct parts of a strand of the Cerberus Fossae fissures. The lavas coursed through Athabasca Valles, overtopping its margins. These overflows surrounded Persbo crater and crossed over lower parts of the wrinkle ridge south of Athabasca Valles to fill the valley to the south of Athabasca Valles. Some of the lava managed to overtop the southern end of this second wrinkle ridge, but the bulk of the volume passed into, and filled, Cerberus Palus. From here, some lava exited to the south through an unnamed channel system that is outside our map area and turned west. The remainder of the lava flowed northeast through Lethe Vallis and an unnamed channel to the north of Lethe Vallis. These lavas then proceeded to the southeast and east, exiting at the southeast corner of our map. The terminus of the lava is approximately $1,500 \mathrm{~km}$ from the vents and the total lava volume is estimated to be 5,000 $\mathrm{km}^{3}$ (Jaeger and others, 2010).

Although a flood of water is not required to explain the features in the valley system, a source of water is still needed to form the phreatovolcanic constructs (also known as rootless cones). Recent modeling suggests that ground ice may have been sufficient to generate the required explosive activity (Dundas and Keszthelyi, 2013). Our preferred geologic history is that only one flood, a turbulent flood of lava, passed through Athabasca Valles.

The final geologic event that our map records is the formation of the last member of the Medusae Fossae Formation. We found clear superposition relations showing that unit AHmf is both above and below unit IAav as reported by Kerber and Head (2010). On the east side of the largest exposure of unit AHmf in our map area, the lava could be seen to embay yardangs (fig. $5 A$ ), positioning the lava stratigraphically above the Medusae Fossae Formation, as expected. However, if unit IAav was emplaced after the deposition of unit AHmf, it is difficult to account for the 20- by $100-\mathrm{km}$ outcrop of unit IAav that is entirely surrounded by unit AHmf (lat $3.75^{\circ} \mathrm{N}$., long $151.31^{\circ} \mathrm{E}$.).

We rejected the hypothesis that these lavas were not part of unit IAav and were erupted within this space because (1) no vent features are within this patch of lava and (2) the lava textures and kinematic indicators in the isolated patch match with those on unit IAav on the other side of the narrow strip of unit AHmf. Furthermore, there are no indications of embayment or other interaction between the lavas and unit AHmf in this area (fig. 5B). Therefore, we concluded that unit AHmf overlies unit IAav in this location, in agreement with Kerber and Head (2010). This is supported by SHARAD data that show a single continuous reflector underneath this part of unit AHmf (Morgan and others, 2015).

There are two possible interpretations of this relation. Either this part of unit AHmf formed after the emplacement of unit IAav or unit IAav lavas were locally invasive and flowed underneath unit $\mathrm{AHmf}$ for several kilometers. There is evidence for invasive lavas in other parts of southern Elysium Planitia (Keszthelyi and others, 2008; Dundas and others, 2016), and the low-density unit $\mathrm{AHmf}$ would be a relatively favorable material for lava to move underneath. However, the invasive flow hypothesis is challenged by the observation of rafted plates on the surface of unit IAav lava with undisturbed yardangs above them (fig. 5B). An invasive flow is generally expected to behave like a sill and have a no-slip upper boundary that would preclude rafting the upper crust apart. Still, given the unusual physical properties of the Medusae Fossae Formation, the invasive lavas plausibly were able to disrupt and transport unit AHmf materials, which would allow the lava crust to raft apart. However, the material that is on top of the lava in this area does not show evidence of having been disrupted in this manner (fig. 5B). In contrast, the hypothesis that this part of unit AHmf was deposited atop the solidified lavas of unit IAav is the more straightforward interpretation of the geologic evidence. Furthermore, it is consilient with our understanding of the geologic context. Specifically, the vigorous lava fountains that fed the eruption that formed unit IAav (Jaeger and others, 
2007) are expected to have produced at least hundreds of cubic kilometers of highly porous pyroclastic rocks and sediments (see Thordarson and Self, 1993) that would have accumulated in this region of Mars (Kerber and others, 2013). This provides a ready source of appropriate material at the appropriate time to form this late member of unit $\mathrm{AHmf}$ at this location. For these reasons, we favored the simpler hypothesis that this area represents a part of unit AHmf that was deposited atop the lavas of unit IAav.

We did not map a variety of even younger surficial materials. Talus is ubiquitous along steep topography such as massifs of unit eNtm, crater rims, and fissure walls. Aeolian deposits are diverse, ranging from basaltic sands that have accumulated in topographic depressions (Jaeger and others, 2010) to the erosional remnants of a widespread mantling deposit that is preserved where indurated by impacts (Preblich and others, 2007). These materials are too discontinuous and (or) small to be effectively represented at the 1:1,000,000 map scale but may be significant units in future large-scale (small area) mapping.

\section{Acknowledgments}

This work was funded between 2008 and 2020 by NASA via agreements NNH06AE14I (Planetary Geology and Geophysics Program), NNH08AJ24I (Mars Fundamental Research Program), NNH07AG45I (Mars Data Analysis Program), NNH16AC85I (Mars Exploration Program), NNH16AC16I (Mars Exploration Program), and 80HQTR18T0020 (Solar Systems Workings Program). The authors gratefully acknowledge the detailed and helpful reviews by Dr. Peter Mouginis-Mark and Dr. Chris Okubo, as well as the extensive assistance of the Planetary Geologic Mapping Program coordinator, the Planetary Geologic Mapping Coordination Team, and the USGS publications group.

\section{References Cited}

Alberti, G., Castaldo, L., Orosei, R., Frigeri, A., and Cirillo, G., 2012, Permittivity estimation over Mars by using SHARAD data - The Cerberus Palus area: Journal of Geophysical Research, v. 117, 11 p., https://doi.org/10.1029/2012JE004047.

Barlow, N.G., 2006, Impact craters in the northern hemisphere of Mars-Layered ejecta and central pit characteristics: Meteoritics and Planetary Science, v. 41, p. 1425-1436.

Berman, D.C., and Hartmann, W.K., 2002, Recent fluvial, volcanic, and tectonic activity on the Cerberus plains of Mars: Icarus, v. 159,17 p.

Boisson, J., Heggy, E., Clifford, S.M., Frigeri, A., Plaut, J.J., Farrell, W.M., Putzig, N.E., Picardi, G., Orosei, R., Lognonne, P., and Gurneet, D.A., 2009, Sounding the subsurface of Athabasca Valles using MARSIS radar data_Exploring the volcanic and fluvial hypotheses for the origin of the rafted plate terrain: Journal of Geophysical Research, v. 114, 11 p., https://doi. org/10.1029/2008JE003299.

Boynton, W.V., Feldman, W.C., Mitrofanov, I.G., Evans, L.G., Reedy, R.C., Squyres, S.W., Starr, R., Trombka, J.I., d'Uston, C., Arnold, J.R., Englert, P.A.J., Metzger, A.E., Wänke, H.,
Brückner, J., Drake, D.M., Shinohara, C., Fellows, C., Hamara, D.K., Harshman, K., Kerry, K., Turner, C., Ward, M., Barthe, H., Fuller, K.R., Storms, S.A., Thornton, G.W., Longmire, J.L., Litvak M.L., and Ton'chev, A.K., 2004, The Mars Odyssey Gamma-Ray Spectrometer instrument suite: Space Science Reviews, v. 110, p. 37-83.

Boynton, W.V., Taylor, G.J., Evans, L.G., Reedy, R.C., Starr, R., Janes, D.M., Kerry, K.E., Drake, D.M., Kim, K.J., Williams, R.M.S., Crombie, M.K., Dohm, J.M., Baker, V., Metzger, A.E., Karunatillake, S., Keller, J.M., Newsom, H.E., Arnold, J.R., Brückner, J., Englert, P.A.J., Gasnault, O., Sprague, A.L., Mitrofanov, I., Squyres, S.W., Trombka, J.I., d'Uston, L., Wänke, H., and Hamara, D.K., 2007, Concentrations of H, Si, $\mathrm{Cl}, \mathrm{K}, \mathrm{Fe}$, and $\mathrm{Th}$ in the low- and mid-latitude regions of Mars: Journal of Geophysical Research, v. 112, 15 p., https://doi. org/10.1029/2007JE002887.

Bradley, B.A., Sakimoto, S.E.H., Frey, H., and Zimbelman, J.R., 2002, Medusae Fossae Formation-New perspectives from Mars Global Surveyor: Journal of Geophysical Research, v. 107, 17 p., https://doi.org/10.1029/2001JE001537.

Burr, D.M., 2003, Hydraulic modeling of Athabasca Vallis, Mars: Hydrological Sciences Journal, v. 48, p. 655-664.

Burr, D.M., 2005, Clustered streamlined forms in Athabasca Valles, Mars - Evidence for sediment deposition during floodwater ponding: Geomorphology, v. 69, p. 242-252.

Burr, D.M., Carling, P.A., Beyer, R.A., and Lancaster, N., 2004, Flood-formed dunes in Athabasca Valles, Mars-Morphology, modeling, and implications: Icarus, v. 171, p. 68-83.

Burr, D.M., Grier, J.A., McEwen, A.S., and Keszthelyi, L.P., 2002, Repeated aqueous flooding from the Cerberus Fossae-Evidence for very recently extant, deep groundwater on Mars: Icarus, v. 159, 53-73.

Burr, D.M., Soare, R.J., Tseung J.-M.W.B., and Emery, J.P., 2005, Young (Late Amazonian), near-surface, ground ice features near the equator, Athabasca Valles, Mars: Icarus, v. 178, p. 56-73.

Carter, L.M., Campbell, B.A., Watters, T.R., Phillips, R.J., Putzig, N.E., Safaeinili, A., Plaut, J.J., Okubo, C.H., Egan, A.F., Seu, R., Biccari, D., and Orosei, R., 2009, Shallow Radar (SHARAD) sounding observations of the Medusae Fossae Formation, Mars: Icarus, v. 199, p. 295-302.

Cassanelli, J.P., and Head, J.W., 2018, Large-scale lava-ice interaction on Mars - Investigating its role during Late Amazonian central Elysium Planitia volcanism and the formation of Athabasca Valles: Planetary and Space Science, v. 158 , p. 96-109.

Cataldo, V., Williams, D.A., Dundas, C.M., and Keszthelyi, L.P., 2015, Limited role for thermal erosion by turbulent lava in proximal Athabasca Valles, Mars: Journal of Geophysical Research Planets, v. 120, p. 1800-1819.

Christensen, P.R., Jakosky, B.M., Kieffer, H.H., Malin, M.C., McSween, H.Y., Jr., Nealson, K., Mehall, G.L., Silverman, S.H., Ferry, S., Caplinger, M., and Ravine, M., 2004, The Thermal Emission Imaging System (THEMIS) for the Mars 2001 Odyssey Mission: Space Science Reviews, v. 110, p. 85-130.

Compton, R.R., 1985, Geology in the field: New York, Wiley Press, 416 p.

Dundas, C.M., and Keszthelyi, L.P., 2013, Modeling steam pressure under martian lava flows: Icarus, v. 226, p. 1058-1067. 
Dundas, C.M., Keszthelyi, L.P., Jaeger, W.L., and Milazzo, M.P., 2016, Tilted-facet terrain of Elysium Planitia, Mars [abs.]: 47th Lunar and Planetary Science Conference, March 21-25, 2016, no. 1903.

Edgett, K.S., Butler, B.J., Zimbelman, J.R., and Hamilton, V.E., 1997, Geologic context of the Mars radar "Stealth" region in southwestern Tharsis: Journal of Geophysical Research, v. 102, p. 21,545-21,567.

Edgett, K.S., and Rice, J.R., 1995, Very young volcanic, lacustrine, and fluvial features of the Cerberus and Elysium basin region of Mars - Where to send the 1999 Mars Surveyor Lander [abs.]: 26th Lunar and Planetary Science Conference, March 13-17,1995, p. 357-358.

Federal Geographic Data Committee [FGDC] [prepared for the Federal Geographic Data Committee by the U.S. Geological Survey], 2006, FGDC Digital cartographic standard for geologic map symbolization: Reston, Va., Federal Geographic Data Committee Document Number FGDC-STD-013-2006, 290 p., 2 plates, https://ngmdb.usgs.gov/fgdc_gds/geolsymstd.php.

Fergason, R.L., and Weller, L., 2018, The importance of geodetically controlled data sets-THEMIS controlled mosaics of Mars, a case study [abs.]: Planetary Science Informatics and Data Analytics Conference, April 24-26, 2018, Lunar and Planetary Institute, contribution no. 2081.

Fergason, R.L., and Weller, L., 2019, The THEMIS controlled mosaics of Mars and final smithed kernels [abs.]: 4th Planetary Data Workshop, June 18-20, 2019, no. 7059, accessed April 2, 2021, at https://www.hou.usra.edu/meetings/planetdata2019/ pdf/7059.pdf.

Gaidos, E., and Marion, G., 2003, Geological and geochemical legacy of a cold early Mars: Journal of Geophysical Research, v. 108, 19 p., https://doi.org/10.1029/2002JE002000.

Golder, K.B., Burr, D.M., and Kattenhorn, S.A., 2020, Investigation of target property effects on crater populations in long lava flows - A study in the Cerberus region, Mars, with implications for magma source identification: Icarus, v. 335, 17 p.

Greeley, R., 1982, The Snake River Plain, Idaho-Representative of a new category of volcanism: Journal of Geophysical Research, v. 87, p. 2705-2712, https://doi.org/10.1029/ JB087iB04p02705.

Greeley, R., and Guest, J.E., 1987, Geologic map of the eastern equatorial region of Mars: U.S. Geological Survey Miscellaneous Investigations Series Map I-1802-B, scale 1:15,000,000.

Hamilton, C.W., Mouginis-Mark, P.J., Sori, M.M., Scheidt, S.P., and Bramson, A.M., 2018, Episodes of aqueous flooding and effusive volcanism associated with Hrad Vallis, Mars: Journal of Geophysical Research Planets, v. 123, p. 1484-1510, https:// doi.org/10.1029/2018JE005543.

Hamilton, C.W., Scheidt, S.P., Bleacher, J.E., Irwin, R.P., and Garry, W.B., 2015, "Fill and spill” lava emplacement associated with the December 1974 flow on Kilauea volcano, Hawaii, USA [abs.]: 46th Lunar and Planetary Science Conference, March 16-20, 2015, no. 1832.

Hanna, J.C., and Phillips, R.J., 2005, Hydrological modeling of the Martian crust with application to the pressurization of aquifers: Journal of Geophysical Research, v. 110, https://doi. org/10.1029/2004JE002330.
Hansen, V.L., 2000, Geologic mapping of tectonic planets: Earth and Planetary Science Letters, v. 176, no. 3-4, p. 527-542.

Harmon, J.K., Arvidson, R.E., Guinness, E.A., Campell, B.A., and Slade, M.A., 1999, Mars mapping with delay-Doppler radar: Journal of Geophysical Research, v. 104, no. E6, p. 14,06514,089 .

Harmon, J.K., Nolan, M.C., Husmann, D.I., and Campbell B.C., 2012, Arecibo radar imagery of Mars - The major volcanic provinces: Icarus v. 220, no. 2 , p. 990-1030.

Harrison, S.K., Balme, M.R., Hagermann, A., Murray, J.B., and Muller, J.-P., 2010, Mapping Medusae Fossae Formation materials in the southern highlands of Mars: Icarus, v. 209, p. 405-415.

Head, J.W., Wilson, L., and Mitchell, K.L., 2003, Generation of recent massive water floods at Cerberus Fossae, Mars, by dike emplacement, cryosphere cracking, and confined aquifer ground release: Geophysical Research Letters, v. 30, no. 11, https://doi. org/10.1029/2003GL017135.

Hoffman, N., and Tanaka, K., 2002, Co-existing "flood" and "volcanic" morphologies in Elysium as evidence for cold $\mathrm{CO}_{2}$ or warm $\mathrm{H}_{2} \mathrm{O}$ outbursts [abs.]: 33rd Lunar and Planetary Science Conference March 11-15, 2002, no. 1505.

Hynek, B.M., Phillips, R.J., and Arvidson, R.E., 2003, Explosive volcanism in the Tharsis region-Global evidence in the Martian geologic record: Journal of Geophysical Research, v. 108, no. E9, 16 p., https://doi.org/10.1029/2003JE002062.

Irwin, R.P., Tanaka, K.L., and Robbins, S.J., 2013, Distribution of Early, Middle, and Late Noachian cratered surfaces in the Martian highlands - Implications for resurfacing events and processes: Journal of Geophysical Research, v. 118, p. 278-291.

Irwin, R.P., Watters, T.R., Howard, A.D., and Zimbelman, J.R., 2004, Sedimentary resurfacing and fretted terrain development along the crustal dichotomy boundary, Aeolis Mensae, Mars: Journal of Geophysical Research, v. 109, 20 p., https://doi. org/10.1029/2004JE002248.

Jaeger, W.L., Keszthelyi, L.P., McEwen, A.S., Dundas, C.M., and Russel, P.S., 2007, Athabasca Valles, Mars-A lava-draped channel system: Science, v. 317, p. 1709-1711.

Jaeger, W.L., Keszthelyi, L.P., McEwen, A.S., Titus, T.N., Dundas, C.M., and Russell P.S., 2008, Response to comment on "Athabasca Valles, Mars - A lava-draped channel system”: Science, v. 320 , p. 1,588 .

Jaeger, W.L., Keszthelyi, L.P., Skinner, J.A., Milazzo, M.P., McEwen, A.S., Titus, T.N., Rosiek, M.R., Galuszka, D.M., Howington-Kraus, E., Kirk, R.L., and the HiRISE Team, 2010, Emplacement of the youngest flood lava on Mars-A short turbulent story: Icarus, v. 205, p. 230-243.

Kerber, L., and Head, J.W., 2010, The age of the Medusae Fossae Formation-Evidence of Hesperian emplacement from crater morphology, stratigraphy, and ancient lava contacts: Icarus, v. 206, https://doi.org/10.1016/j.icarus.2009.10.001.

Kerber, L., and Head, J.W., 2012, A progression of induration in Medusae Fossae Formation transverse aeolian ridges - Evidence for ancient aeolian bedforms and extensive reworking: Earth Surface Processes and Landforms, v. 37, p. 422-433.

Kerber, L., Forget, F., Madeleine, J.-B., Wordsworth, R., Head, J.W., and Wilson, L., 2013, The effect of atmospheric pressure on the dispersal of pyroclasts from martian volcanoes: Icarus, $\mathrm{v}$. 223, p. 149-156. 
Keszthelyi, L.P., Denlinger, R.P., O’Connell, D.R.H., and Burr, D.M., 2007, Initial insights from 2.5D hydraulic modeling of floods in Athabasca Valles, Mars: Geophysical Research Letters, v. 34, 5 p., https://doi.org/10.1029/2007GL031776.

Keszthelyi, L.P., Jaeger, W.L., Dundas, C.M., Martinez-Alonso, S., McEwen, A.S., and Milazzo, M.P., 2010, Hydrovolcanic features on Mars - Preliminary analysis of one Mars year of HiRISE observations: Icarus, v. 205, p. 211-229.

Keszthelyi, L.P., Jaeger, W., McEwen, A., Tornabene, L., Beyer, R.A., Dundas, C., and Milazzo, M., 2008, High Resolution Imaging Science Experiment (HiRISE) images of volcanic terrains from the first 6 months of the Mars Reconnaissance Orbiter Primary Science Phase: Journal of Geophysical Research, v. 113, 25 p., https://doi.org/10.1029/2007JE002968.

Keszthelyi, L.P., McEwen, A.S., and Thordarson, Th., 2000, Terrestrial analogs and thermal models for Martian flood lavas: Journal of Geophysical Research, v. 105, p. 15,027-15,050.

Keszthelyi, L.P., Self, S., and Thordarson, Th., 2006, Flood lavas on Earth, Io, and Mars: Journal of the Geological Society of London, v. 163, p. 253-264.

Keszthelyi, L.P., Thordarson, Th., McEwen, A., Haack, H., Guilbaud, M-N., Self, S., and Rossi, M., 2004, Icelandic analogs to Martian flood lavas: Geochemistry, Geophysics Geosystems, v. 5, 31 p., https://doi.org/10.1029/2004GC000758.

Kirk, R.L., Lee, E.M., Sucharski, R.M., Richie, J., Grecu, A., and Castro, S.K., 2000, MDIM 2.0-A revised global digital image mosaic of Mars [abs.]: 31st Lunar and Planetary Science Conference, March 13-17, 2000, no. 2011.

Malin, M.C., Bell III, J.F., Cantor, B.A., Caplinger, M.A., Calvin, W.M., Clancy, R.T., Edgett, K.S., Edwards, L., Haberle, R.M., James, P.B., Lee, S.W., Ravine, M.A., Thomas, P.C., and Wolff, M.J., 2007, Context camera investigation on board the Mars reconnaissance orbiter: Journal of Geophysical Research, v. 112, 25 p., https://doi.org/10.1029/2006JE002808.

Mandt, K.E., de Silva, S.L., Zimbelman, J.R., and Crown, D.A., 2008, Origin of the Medusae Fossae Formation, Mars - Insights from a synoptic approach: Journal of Geophysical Research, v. 113, no. E12, 15 p., https://doi.org/10.1029/2008JE003076.

Mandt, K., de Silva, S., Zimbelman, J., and Wyrick, D., 2009, Distinct erosional progressions in the Medusae Fossae Formation, Mars, indicating contrasting environmental conditions: Icarus, v. 204, p. 471-477.

Manga, M., 2004, Martian floods at Cerberus Fossae can be produced by groundwater discharge: Geophysical Research Letters, v. 31, 4 p., https://doi.org/10.1029/2003GL018958.

McEwen, A.S., Eliason, E.M., Bergstrom, J.W., Bridges, N.T., Hansen, C.J., Delamere, W.A., Grant, J.A., Gulick, V.C., Herkenhoff, K.E., Keszthelyi, L.P., Kirk, R.L., Mellon, M.T., Squyres, S.W., Thomas, N., and, Weitz, C.M., 2007, MRO's High Resolution Imaging Science Experiment (HiRISE): Journal of Geophysical Research, v. 112, 40 p., https://doi. org/10.1029/2005JE002605.

McEwen, A.S., Preblich, B.S., Turtle, E.P., Artemieva, N.A., Golombek, M.P., Hurst, M., Kirk, R.L., Burr, D.M., and Christensen, P.R., 2005, The rayed crater Zunil and interpretations of small impact craters on Mars: Icarus, v. 176, p. 351-381.

Michael, G.G., 2013, Planetary surface dating from crater sizefrequency distribution measurements-Multiple resurfacing episodes and differential isochron fitting: Icarus, v. 226, p. 885-890.

Morgan, G.A., Campbell, B.A., Carter, L.M., Holt, J.W., Plaut, J.J., and Jasper, A., 2017, Reconstructing the buried floor of Athabasca Valles - Increased channel depth estimates from radar studies [abs.]: 48th Lunar and Planetary Science Conference, March 20-24, 2017, no. 2563.

Morgan, G.A., Campbell, B.A., Carter, L.M., and Plaut, J.J., 2015, Evidence for the episodic erosion of the Medusae Fossae Formation preserved within the youngest volcanic province on Mars: Geophysical Research Letters, v. 42, 7 p., https://doi. org/10.1002/2015GL065017.

Mouginis-Mark, P.J., 1985, Volcano/ground ice interactions in Elysium Planitia, Mars: Icarus, v. 64, p. 265-284, https://doi. org/10.1016/0019-1035(85)90090-9.

Mouginis-Mark, P.J., 1993, The influence of oceans on Martian volcanism [abs.]: 24th Lunar and Planetary Science Conference, March 15-19, 1993, p. 1021-1022.

Muhleman, D.O., Bulter, B.J., Grossman, A.W., Slade, M., and Jurgens, R., 1991, Radar images of Mars: Science, v. 253, p. 1508-1513.

Murray, J.B., Muller, J-P., Neukum, G., Werner, S.C., van Gasselt, S., Hauber, E., Markiewicz, W.J., Head III, J.W., Foing, B.H., Page, D., Mitchell, K.L., Portyankina, G., and the HRSC Co-Investigator Team, 2005, Evidence from the Mars Express High Resolution Stereo Camera for a frozen sea close to Mars' equator: Nature, v. 434, p. 352-256.

Noguchi, R., and Kurita, K., 2015, Unique characteristics of cones in central Elysium Planitia, Mars: Planetary and Space Science, v. 111, p. 44-54.

Ohja, L., and Lewis, K., 2018, The density of the Medusae Fossae Formation-Implications for its composition, origin, and importance in Martian history: Journal of Geophysical Research Planets, v. 123, p. 1368-1379, https://doi. org/10.1029/2018JE005565.

Okubo, C.H., and Schultz, R.A., 2003, Thrust fault vergence direction on Mars - A foundation for investigating global-scale Tharsis-driven tectonics: Geophysical Research Letters, v. 30, no. 22, 4 p., https://doi.org/10.1029/2003GL018664.

Page, D.P., 2007, Recent low-latitude freeze-thaw on Mars: Icarus, v. 189, p. $83-117$.

Page, D.P., 2010, Resolving the Elysium controversy-An open invitation to explain the evidence: Planetary and Space Science, v. 58, p. 1406-1413.

Page, D.P., and Murray, J.B., 2006, Stratigraphic and morphologic evidence for pingo genesis in the Cerberus plains: Icarus, v. 183, p. 46-54.

Pedersen, G.B.M., 2013, Frozen Martian lahars? Evaluation of morphology, degradation and geologic development in the Utopia-Elysium transition zone: Planetary and Space Science, v. 85, p. 59-77, https://doi.org/10.1016/j.pss.2013.05.020.

Peterson, D.W., and Tilling, R., 1980, Transition of basaltic lava from pahoehoe to aa, Kilauea Volcano, Hawaii-Field observations and key factors: Journal of Volcanology and Geothermal Research, v. 7, p. 271-293.

Platz, T., and Michael, G., 2011, Eruption history of the Elysium volcanic province, Mars: Geophysical Research Letters, v. 312, p. $140-151$. 
Plescia, J.B., 1990, Recent flood lavas in the Elysium region of Mars: Icarus, v. 88, p. 465-490.

Plescia, J.B., 2003, Cerberus Fossae, Elysium, Mars-A source for lava and water: Icarus, v. 164, p. 79-95.

Preblich, B.S., McEwen, A.S., and Studer, D.M., 2007, Mapping rays and secondary craters from the Martian crater Zunil: Journal of Geophysical Research, v. 112, https://doi. org/10.1029/2006JE002817.

Rice, J.W., Jr., Parker, T., Russel, A.J., and Knudsen, O., 2002, Morphology of fresh outflow channel deposits on Mars [abs.]: 33rd Lunar and Planetary Science Conference, March 11-15, 2002, no. 2026.

Robbins, S.J., and Hynek, B.M., 2012, A new global database of Mars impact craters $\geq 1 \mathrm{~km}-1$. Database creation, properties, and parameters: Journal of Geophysical Research, v. 117, no. E6, 21 p., https://doi.org/10.1029/2011JE003967.

Rowland, S.K., and Walker, G.P.L., 1990, Pahoehoe and aa in Hawaii-Volumetric flow rate controls the lava structure: Bulletin of Volcanology, v. 52, p. 615-628.

Ruff, S.W., and Christensen, P.R., 2002, Bright and dark regions on Mars-Particle size and mineralogical characteristics based on Thermal Emission Spectrometer data: Journal of Geophysical Research, v. 107, 22 p., https://doi. org/10.1029/2001JE001580.

Ryan, A.J., and Christensen, P.R., 2012, Coils and polygonal crust in the Athabasca Valles region, Mars, as evidence for a volcanic history: Science, v. 336, p. 449-452.

Salvador, A., ed., 1994, International stratigraphic guide-A guide to stratigraphic classification, terminology, and procedure $(2 \mathrm{~d}$ ed.): Boulder, Colo., Geological Society of America, 214 p., https://doi.org/10.1130/9780813774022.

Schultz, P., and Lutz, A.B., 1988, Polar wandering on Mars: Icarus, v. 73, p. 91-141.

Scott, D.H., and Allingham, J.W., 1976, Geologic map of the Elysium quadrangle of Mars: U.S. Geological Survey Miscellaneous Investigations Series Map I-935, scale 1:5,000,000.

Scott, D.H., and Tanaka, K.L., 1982, Ignimbrites of Amazonis Planitia region of Mars: Journal of Geophysical Research, v. 87, no. B2, p. 1179-1190.

Scott, D.H., and Tanaka, K.L., 1986, Geologic map of the western equatorial region of Mars: U.S. Geological Survey Miscellaneous Investigations Series Map I-1802-A, scale 1:15,000,000.

Seu, R., Biccari, D., Orosei, R., Lorenzoni, L.V., Phillips, R.J., Marinangeli, L., Picardi, G., Masdea, A., and Zampolini, E., 2004, SHARAD — The MRO 2005 shallow radar: Planetary and Space Science, v. 52, p. 157-166.

Skinner, J.A., and Tanaka, K.L., 2018, Geological map of the Nepenthes Planum region, Mars: U.S. Geological Survey Scientific Investigations Map 3389, pamphlet 11 p., scale 1:1,506,000.

Suppe, J., 1983, Geometry and kinematics of fault-bend folding: American Journal of Science, v. 283, p. 684-721.

Tanaka, K.L., Chapman, M.C., and Scott, D.H., 1992, Geologic map of the Elysium region of Mars: U.S. Geological Survey Miscellaneous Investigation Series Map I-2147, scale 1:5,000,000.

Tanaka, K.L., and Scott, D.H., 1986, The youngest channel system on Mars [abs.]: 17th Lunar and Planetary Science Conference, March 17, 1986, p. 44.
Tanaka, K.L., Skinner, J.A., Jr., Dohm, J.M., Irwin, R.P., III, Kolb, E.J., Fortezzo, C.M., Platz, T., Michael, G.G., and Hare, T.M., 2014, Geologic map of Mars: U.S. Geological Survey Scientific Investigations Map 3292, scale 1:20,000,000, pamphlet 43 p., https://dx.doi.org/10.3133/sim3292.

Tanaka, K.L., Skinner, J.A., Jr., and Hare, T.M., 2005, Geologic map of the northern plains of Mars: U.S. Geological Survey Scientific Investigations Map 2888, scale 1:15,000,000.

Tanaka, K.L., Skinner, J.A, Jr., and Hare, T.M., 2011, Planetary geologic mapping handbook-2011: U.S. Geological Survey, Astrogeology Science Center, unpublished handbook, accessed March 4, 2021, at https://astropedia.astrogeology.usgs.gov/ download/Docs/Mappers/PGM_Handbook_2011.pdf.

Thomas, R.J., 2013, Identification of possible recent water/lava source vents in the Cerberus plains - Stratigraphic and crater count age constraints: Journal of Geophysical Research, v. 118, p. 789-802.

Thordarson, Th., and Self, S., 1993, The Laki (Skaftár Fires) and Grímsvötn eruptions in 1783-1785: Bulletin of Volcanology, v. 55, p. 233-263.

Vaucher, J., Baratoux, D., Mangold, N., Pinet, P., Kurita, K., and Grégoire, M., 2009, The volcanic history of central Elysium Planitia-Implications for martian magmatism: Icarus, v. 204, p. 418-442, https://doi.org/10.1016/j. icarus.2009.06.032.

Watters, T.R., Campbell, B., Carter, L., Leuschen, C.J., Plaut, J.J., Picardi, G., Orosei, R., Safaeinili, A., Clifford, S.M., Farrell, W.M., Ivanov, A.B., Phillips, R.J., and Stofan, E.R., 2007, Radar sounding of the Medusae Fossae Formation MarsEquatorial ice or dry, low-density deposits?: Science, 318, 1125-1128.

Werner, S.C., 2009, The global martian volcanic evolution history: Icarus, v. 201, p. 44-68, https://doi.org/10.1016/j.icarus.2008.12.019.

Werner, S.C., Ivanov, B.A., and Neukum, G., 2009, Theoretical analysis of secondary cratering on Mars and an image-based study on the Cerberus plains: Icarus, v. 200, p. 406-417.

Werner, S.C., and Tanaka, K.L., 2011, Redefinition of the craterdensity and absolute-age boundaries for the chronostratigraphic systems of Mars: Icarus, v. 215, no. 2, p. 603-607, https://doi. org/10.1016/j.icarus.2011.07.024.

Werner, S.C., van Gasselt, S., and Neukum, G., 2003, Continual geologic activity in Athabasca Valles, Mars: Journal of Geophysical Research, v. 108, 10 p., https://doi. org/10.1029/2002JE002020.

Wilson, L., and Mouginis-Mark, P.J., 2014, Dynamics of a fluid flow on Mars - Lava or mud?: Icarus, v. 233, p. 268-280, https://doi.org/10.1016/j.icarus.2014.01.041.

Zimbelman, J.R., and Griffin, L.J., 2010, HiRISE images of yardangs and sinuous ridges in the lower member of the Medusae Fossae Formation, Mars: Icarus, v. 205, p. 198-210.

Zimbelman, J.R., and Scheidt, S.P., 2012, Hesperian age for western Medusae Fossae Formation, Mars: Science, v. 336, no. 6089, p. 1,683, https://doi.org/10.1126/science.1221094.

Zuber, M.T., Smith, D.E., Solomon, S.C., Muhleman, D.O., Head, J.W., Garvin, J.B., Abshire, J.B., and Bufton, J.L., 1992, The Mars Observer laser altimeter investigation: Journal of Geophysical Research, v. 97, p. 7781-7797. 